\title{
ABOUT IODIDE: A FRIENDLY AND NECESSARY ION
}

Key-words: lodide, salt iodination, ioduria, iodide deficiency, goiter, thyroid cancer

Maria Lúcia D’Arbo Alves - Departamento de Clínica Médica, Universidade de Ribeirão Preto (UNAERP), Ribeirão Preto, São Paulo, Brazil

Anderson Marliere Navarro- Departamento de Ciências da Saude, Divisão de Nutrição e Metabolismo, Faculdade de Medicina de Ribeirão Preto (FMRP), Ribeirão Preto, São Paulo, Brazil

Corresponding Author: Maria Lúcia D’Arbo Alves

EMAIL: mldarbo@bol.com.br 


\section{ABSTRACT}

lodide is an essential micronutrient present in very small quantities in the human body, with a fundamental action for the adequate synthesis of thyroid hormones, which are critical for cell differentiation, growth and metabolism. In the form of iodide, iodine is widely distributed in the environment, although in an irregular manner, occurring in abundant amounts in the oceans and in coastal areas and scarcely found on islands and mountains. The diet is the main source of iodine, whose intake varies according to the amount present in soil and water and according to eating habits. Governmental policies have been adopted to satisfy and guarantee the necessary daily supply of iodine, such as fortification of industrialized salt for domestic iodine consumption or addition to the bread commonly consumed in a given region, or the offer of iodized oil to the population, or even iodine supplementation through medications. lodide deficiency is the main avoidable cause of brain damage to fetuses and children, as well as retardation of psychomotor development. Thyroid hormones are almost universally involved in the development and proliferation of fetal neural tissue. Permanent lesions of the cerebral cortex, hippocampus and cerebellum may occur, with loss of, or damage to the brainstem or spinal cord, affecting cortical areas that integrate highly specialized stimuli, which become poorly defined on an anatomical basis, including silent areas of the associative cortex. One of the more significant metabolic problems due to dietary iodine deficiency is the presence of goiter (increased volume of the thyroid gland). Thyroid carcinoma is the most frequent endocrine neoplasia affecting the human species and plasma iodine concentration is related to the development of specific subtypes of this neoplasia. An increased prevalence of follicular carcinoma, a more aggressive tumor, has been observed in areas of iodine deficiency, while the correction of this deficiency is associated with a higher prevalence of papilliferous carcinoma, a less aggressive form.

CONCLUSION: An ideal plasma iodide concentration is necessary to insure the proper mental development of fetuses and young children and to minimize the aggressiveness of thyroid cancer from follicular cells in humans. 


\section{INTRODUCTION}

lodine, from the Greek "iodes", which means "violet" (1), is an essential micronutrient present in very small quantities in the human body $\left(0.02285 \times 10^{\sim} \%\right.$ adult body weight $)(2,3)$. It is consumed in the water or in food as iodine (element with no charge) or iodide (ion with a negative charge), which is converted to iodine in the stomach.

lodine is a fundamental nutrient for the appropriate synthesis of thyroid hormones, which are critical for cell differentiation, growth and metabolism. It represents $65 \%$ of the molecular weight of thyroxine (T4) and 59\% of triiodothyronine (T3) $(4,5)$. In the iodide form, iodine is widely distributed in the environment, although in an irregular form, being found in abundant quantities in the oceans and coastal areas and in scarce amounts on islands and mountains (6).

The diet and food supplements containing iodine are the main source of iodine, and its plasma levels are also partially replaced by iodothyronine deiodization in the thyroid cells $(6,7,8,9,10,11)$.

For many years iodine deficiency was believed to be a problem limited to certain geographic regions and to some special situations (nutrition or malnutrition) and was considered to have a specific clinical spectrum (hypothyroidism, goiter and brain damage, with the possible occurrence of cretinism) $(12,13,14)$. However, the reemergence of iodine deficiency has been observed in certain areas of industrialized centers, raising concern about its cognitive consequences $(15,16)$.

This essentiality of iodine is more evident during the initial stages of intrauterine life, implying the need for an adequate iodine intake during pregnancy in order to obtain optimum fetal neurodevelopment. The fetus, followed by the newborn and the child in the first stages of life, represent the phases most vulnerable to iodine deficiency (17).

The first 1000 days of life are considered to be the window of opportunity for potential interventions in the prevention of damage to the human neurological potential, with consequences for the intelligence quotient (IQ) or hyperactivity with attention deficit (17).

lodine intake varies according to the quantity of iodine in the soil and water and to the eating habits of a given region $(11,12,13)$.

The World Health Organization (WHO), the United Nations Children's Fund (UNICEF) and the International Council for the Control of lodine Deficiency Disorders (ICCIDD) recommend an iodine intake of $90 \mathrm{mg} /$ day for children aged 0 to 5 years, of about $120 \mu \mathrm{g} /$ day for children aged 6 to 12 years, of $150 \mu \mathrm{g} /$ day for adults older than 12 years, and of $250 \mu \mathrm{g} /$ day for pregnant and lactating women (18).

In a study on Latin America, the mean iodine content in the salt varied outside the recommended 20-40 parts per million (ppm), and was greater than $78 \mathrm{ppm}$ in $83 \%$ of all samples, demonstrating achievement in the elimination of iodine deficiency in most of the countries studied (19). 
From 2005 on, the WHO determined that each country should make its own reports on the iodine deficiency situation every 3 years. Founded in 1986, the lodine Global Network (IGN) is now the authoritative voice for iodine nutrition.

lodine requirements increase during pregnancy not only because of the fetal needs, but also because of the change in maternal thyroid physiology. Pregnancy is accompanied by significant changes in thyroid function. During the first phase of gestation, the chorionic gonadotropin produced by the placenta stimulates the maternal thyroid, exerting an effect resembling that of thyroid-stimulating hormone (TSH) due to the structural homology between the molecules, directly stimulating the maternal thyroid. During this period, the fetal thyroid is fully dependent on the maternal thyroid $(10,20,21,22)$. Although the fetal thyroid starts its activity between the 18th and 20th weeks of pregnancy, the fetal iodine supply continues to depend on the mother (23).

Gestation involves a high thyroid hormone demand and in pregnant women who ingest an adequate quantity of iodine the release of thyroid hormone reaches a new balance which is maintained until the end of pregnancy. The increased thyroid hormone requirements are satisfied by a proportional increase in the synthesis and release of these hormones which directly depend on maternal iodine intake and, the greater the iodine deficiency, the worse the maternal-fetal consequences $(10,14,15,24,25,26)$. An inadequate thyroid response has been observed in healthy pregnant women residing in areas of medium to moderate iodine deficiency $(24,25,26)$ (fig 1 ).

About $10 \%$ of ingested iodine is utilized by the thyroid in areas of iodine sufficiency and up to $80 \%$ is utilized in cases of iodine deficiency (27) (fig 1).

Most of the daily ingested iodine is eliminated through the urine as ioduria, which ranges from $100 \mu \mathrm{g} / \mathrm{L}$ to $300 \mu \mathrm{g} / \mathrm{L}$ under normal intake conditions for nonpregnant adults, and this excretion is a good indicator of dietary iodine intake $(27,28,29,30)$ (fig 1$)$.

The normal thyroid is the largest iodine reservoir in the organism, containing about 5 to $10 \mathrm{mg}$ iodide, and functions as a reservoir of hormones and iodized tyrosine, being able to protect the organism from iodine deficiency for a certain period of time $(28,29,30)$ (fig 1$)$.

In the presence of iodine deficiency, the thyroid adapts by increasing its uptake with an initially diffuse increase in glandular mass which tends to become nodular in cases of chronic deficiency, and by inducing preferential T3 secretion and increased TSH synthesis and release $(30,31)$. These hormones act directly or indirectly on many metabolic and developmental processes such as thermal and metabolic regulation, somatic growth and central nervous system growth $(28,29,31,32,33)$ (fig 1$)$.

Excessive iodine intake on a chronic basis is also harmful, triggering goiter, chronic thyroiditis and subclinical hyperthyroidism in the exposed population $(34,35,36)$.

The synthesis of thyroid hormones involves the following steps and utilizes the following proteins $(37,38,39,40,41,42,43)($ fig 1$)$ :

1) Stimulation of follicular thyroid cells by TSH at the TSH receptor protein site 
2) Active iodine transport through the basement membrane into the follicular thyroid cells, with a concentration of intracellular iodine about 20 to 50 times higher than in plasma. This is an active process that uses the sodium iodide symporter (NIS) which functions as a pump, co-transporting one iodine ion together with two $\mathrm{Na}^{+9}$ (sodium) ions and using the energy generated by $\mathrm{Na}^{+} / \mathrm{K}^{+}$ATPase, which maintains a low concentration of intracellular $\mathrm{Na}^{+}$. NIS also transports other ions such as pertectanate $\left(\mathrm{TcO}_{4}{ }^{-}\right)$, sulfocyanide $\left(\mathrm{SCN}^{-}\right)$, perchlorate $\left(\mathrm{ClO}_{4}{ }^{-}\right)$, and nitrate $\left(\mathrm{NO}_{3}{ }^{-}\right)$. lodine transport by NIS is stimulated by TSH and by a mechanism of self-regulation, with NIS activity varying in an inverse manner in relation to intraglandular iodine concentration

3) Inside the follicular cells, iodine is transported to the colloid, an action performed by the protein pendrin, which acts as an iodine/chloride transporter.

4) Iodine organification, whereby iodine is rapidly incorporated into the tyrosine residues of thyroglobulin ( $\mathrm{Tg}$ ) (a glycoprotein representing the principal content of colloid) by hydrogen peroxide $\left(\mathrm{H}_{2} \mathrm{O}_{2}\right)$, a reaction catalyzed by the enzyme thyroperoxidase (TPO).

5) Coupling of the iodotyrosine molecules in Tg forming the iodothyronines T3 and T4 through the action of tyroperoxidase (TPO).

The processes of iodine oxidation and organification and the coupling reaction of iodotyrosines are catalyzed by TPO, which utilizes the $\mathrm{H}_{2} \mathrm{O}_{2}$ produced by the hydrogen peroxide generator proteins, NADPH-oxidase - the thyroid oxidase (ThOx 1 and ThOx 2) which are two dual oxidases (DUOX 1 and DUOX 2, the latter being more efficient for $\mathrm{H}_{2} \mathrm{O}_{2}$ production).

6) Colloid endocytosis, Tg proteolysis and release of free iodothyronines (T3 and T4).

7) Intrathyroid deiodination of monoiodoyrosine (MIT) and diiodotyrosine (DIT) by the enzyme dehalogenase (DEHAL-1)

8) Before T4 secretion, part of it undergoes intrathyroid deiodination and forms T3, increasing the quantity of released $\mathrm{T} 3$ and rendering the hormone synthesis more efficient

9) The total plasma T4 content is about 45 times higher than the content of T3, with the main source of $\mathrm{T} 3$ production being the conversion of $\mathrm{T} 4 \mathrm{to} \mathrm{T} 3$ by a deiodase enzyme in peripheral tissues

lodine deficiency is the main available cause of brain damage to fetuses and children and of retardation of psychomotor development. Thyroid hormones are almost universally involved in the development and proliferation of fetal neural tissue. Permanent damage to the cerebral cortex, hippocampus and cerebellum may occur, with loss of, or damage to, the brainstem or spinal cord, affecting cortical areas that 
integrate highly specialized stimuli, which become poorly defined on an anatomical basis, including silent areas of the associative cortex $(44,45,46)$ ( fig 1$)$.

The period of response of the fetal nervous cells is called "competence" and these cells do not respond either before or after this period, a fact that implies a sequence of maturation that does not involve a sequence of independent events, but rather a cascade of interlinked events $(47,48,49)$. Maternal thyroid hormone deficiency causes gestational hypothyroidism, which in turn causes blurred neonatal layering (49).

Maternal hypothyroidism (increased TSH and normal or reduced free T4) was believed to be the factor responsible for changes in the fetal neurological development during the early stages of pregnancy. However, recent experimental studies have shown that the fetal neurological development is affected not only in the presence of maternal hypothyroidism, but also in the presence of maternal hypothyroxinemia during the early stages of pregnancy (free T4 below the 2.5 percentile, with TSH within the normal reference range), causing brain damage (50).

Maternal iodine deficiency may lead to maternal hypothyroidism or hypothyroxinemia. In the presence of maternal hypothyroidism there is no transfer of thyroid hormone to the fetus, while this transfer does occur in the presence of maternal hypothyroxinemia. Early thyroid hormone replacement in the newborn can prevent or reduce fetal brain damage. Fetal brain damage can be severe in the presence of maternal hypothyroidism or may be medium/moderate or severe in the presence of maternal hypothyroxinemia $(50,51,52)$ (fig 1$)$.

The fetal thyroid is protected from the maternal hormonal fluctuations by safety mechanisms such as physical barriers (placenta and ovular membranes) which prevent the free transfer of thyroid hormone from mother to fetus due to the presence of the enzyme decodes (particularly of type 2 ) in the placenta and in the fetal brain tissue responsible for the conversion of maternal T4 to T3 since the direct maternal transfer of T3 to the fetus is extremely low $(53,54,55,56,57)$.

In iodine-deficient areas the organism activates mechanisms of self-regulation, with preferential T3 synthesis at the expense of T4 as a way to conserve iodine, causing maternal hypothyroxinemia (reduced T4, maintenance of circulating T3, and TSH levels within the normal range). Maternal hypothyroxinemia during the first half of pregnany is associated with permanent and irreversible fetal brain damage, reflecting the maternal inability to transfer T4 to the embryo in an adequate manner, with permanent cognitive and behavioral sequelae $(57,58,59,60)$ (fig 1$)$.

Human cortical development occurs between the 6th and 24th week of pregnancy and the thyroid hormones are directly or indirectly involved in most of the processes of neurodevelopment of embryo and fetus. This would explain the irreversible effects of this deficiency during early gestation $(44,45,46,47,48,49,50)$. 
Thyroid hormone receptors are largely expressed in neurons and glial cells (astrocytes and oligodendritic cells), in dendrite growth and synapse formation, myelinization, and migration of specific cells in neuronal organization (synapses, transmission, laminal cytoarchitecture in the cerebral cortex, and appropriate glial interactions) $(44,45,46)$.

Government policies have been adopted in order to satisfy and guarantee the necessary daily supply of iodine, such as iodine fortification of industrialized salt for domestic consumption or the addition of iodine to bread in a given region, the offer of iodized oil to the population, or even iodine supplementation through medications.

One of the most significant metabolic problems due to dietary iodine deficiency is the presence of goiter (increased volume of the thyroid gland).

In 1918, when the United states of America were preparing to enter World War I, an examiner for the selection of soldiers in Houghton County, Michigan, rejected about $30 \%$ of the potential recruits due to the presence of goiter and/or hypothyroidism. A study conducted at that same time on schoolchildren in the state of Michigan detected about $47.2 \%$ of the children examined with signs/symptoms of goiter and severe thyroid dysfunction (1).

At that time there was some debate about the severity of the situation around the belt of the American Great Lakes and about the iodine deficiency in that region. It was proposed to offer the children iodized syrup about 2 to 3 times a year, but that policy proved to be inadequate. In Rochester, New York, the proposal of adding iodine to the water consumed by the population of the city also failed (1).

In 1922, David Murray Cowie, a pediatrician at the University of Michigan, entered the fight against goiter by monitoring children with severe hypothyroidism and important intellectual damage leading to mental deficiency. One day, he had the opportunity to read a long monograph about the health authorities of Switzerland, another part of the world with iodine-deficient soil, which described a plan for the prevention of goiter by adding a specific amount of sodium or potassium iodide to the salt for domestic consumption commercially sold in the country. Cowie believed that, since everybody uses salt for the preparation of daily foods, he could convince the salt industries to change their product by adding iodine to it, a measure that could solve a serious public health problem. However, this proved not to be very easy and two years of intense work and education would be needed in order to obtain an effect (1).

Cowie was able to achieve the result that iodine would be added to virtually all salt processed in and around the state of Michigan and the chemist of Dow Chemical Company would also demonstrate that the small quantity of iodine added to salt (about $0.1 \%$ of the total content) did not alter the flavor or function of salt (1). Cowie, known since then as the "salt man", convinced the medical class that adding iodine to salt would not increase the risk of hyperthyroidism or heart damage. Working with a competent medical team, he was able to obtain a referendum from 
the Medical society of the state of Michigan regarding the use of iodized salt and, in addition, he traveled around the country offering public health lectures for the prevention of goiter and hypothyroidism with the use of iodized salt. lodized salt started to be progressively commercialized throughout the country and the salt industry voluntarily switched to the production of only iodized salt (1).

In 1980, all the consequences of the lack of iodine, ranging from goiter to mental retardation, were gathered under the term "iodine deficiency disorders" (IDDs) and the measurement of UCF levels became the best tool to monitor population iodine deficiency status. In 1994, in an attempt to reduce the prevalence of iodine deficiency worldwide, the WHO recommended eliminating IDDs by iodizing all salt for human consumption (61).

The programs of industrialized salt iodination for domestic consumption, the strategies of iodine supplementation or fortification and silent iodine prophylaxis have contributed to the progressive eradication of iodine deficiency during the fetal life and the first months of extra uterine life $(11,12)$ and have also contributed to the reduction of goiter.

In spite of the amelioration of iodine consumption by the general population of many countries, a new scenario has arisen involving impaired cognitive outcomes with a gamut of behavioral disorders such as attention-deficit/hyperactivity disorder (ADHD) or autism $(62,63)$. ADHD has been described in newborns in the presence of hyperthyroidism (64), iodine deficiency (65), hypothyroxinemia (63), and mild maternal thyroid-hormone insufficiency (66).

"Nurturing care" is the term that has been coined to include nutritional, environmental and emotional support to promote the development of key brain regions that have lifelong benefits, including improved health and wellbeing, and increased ability to learn and earn $(67,68)$. Adequate iodine intake is essential for this goal to be reached with supplementation during multiple and overlapping critical timewindows when development of specific capacities and abilities can be most powerfully enhanced (69).

\section{CONCLUSION}

lodine plays a fundamental role in the human species and the ideal plasma concentration of this ion prevents mental retardation/cretinism in fetuses and small children, also causing the thyroid neoplasias expressed by this gland to be less aggressive (papilliferous rather than follicular subtype). lodine is a friendly and necessary ion at ideal concentrations for the human species $(68,69,70,71,72,73,74)$. 


\section{REFERENCES}

1. Leung AM, Braverman LE, Pearce EM. 2012. History of US lodine fortification and supplementation.Nutrients 4 (11): 1740-6.

2. Elementos traço na nutrição e saúde. 1998. Organização Mundial de Saúde (OMS), São Paulo, Rocco.

3. Dietary References Intake. Dietary reference intakes for vitamin A, vitamin K, arsenic, boron, chromium, copper, iodine, iron, manganese, molybdenum, nickel, silicone, vanadium and zinc. Food and Nutrition Board. 2001. Washington; National Academy Press; p258-89.

4. Bianco AC. Fisiologia da glândula tireoide. In; Rosa JC, Romão LA, eds. Glândula tireoide: funções e disfunções- diagnóstico e tratamento.2001. 2ª ed São Paulo, Lemos. p33-46.

5. Norman AW, Libwack G. Hormones. 1997.2 ${ }^{\text {nd }}$ ed San Diego; Academic.

6. Greenspan FS. 2006.A glândula tireoide. In: Greenspan FS, Gardner DG, editores. Endocrinologia clínica e básica. 7 ed Porto Alegre. AMGH; P181-202.

7. Llop S, Lopez-Espinosa MJ, Murcia M, Alvarez-Pedrerol M, Vloque J, Aguinabalde X, et al. 2015. Synergism between exposure to mercury and use of iodine supplements on thyroid hormones in pregnant women. Environ Res; 138-305.

8. Anees M, Anis RA, Yousaf S, Murtaza I, Sultan A, Arslan M et al. 2015. Effect of maternal iodine supplementation on thyroid function and birth outcome in goiter endemic areas. Curr Med Res Opin); 31(4):667-74.

9. Lewandowiski TA, Peterson MK, Charnley G. 2015lodine supplementation and drinkingwater perchlorate mitigation. Food Chem Toxicol; 80:261-270.

10. Zimmermann, MB, Gizak M, Abbott K, Anderson M, Lazarus JH. 2015.lodine deficiency in pregnant women in Europe. Lancet Diabetes Endocrinol; 3:672-4.

11. Vanderpump, MP. 201.Epidemiology of iodine deficiency. Minerva Med; 108 :116-123.

12. Hetzel BS. 1983lodine deficiency disorders (IDD) and their eradications. Lancet;2:116-123.

13. Niwattisamong S, Burman KD, Li-Ng M. 2017.lodine deficiency: Clinical implications. Clev Clin J of Med; 84,3(March): 236-44.

14. Zimmermann MB. 2016. The importance of adequate lodine during pregnacy and infancy. World Rev Nutr Diet; 115:118-24.

15. Trumpff C, De Schepper J, Tafforeau J, Van Oyen H, Vanderfaeillie J, Vandevijvere S. 2013. Mild iodine defiency in pregnancy in Europe and its consequences for cognitive and psychomotor development of children: A review. J Trace Elem Med Biol; 27:174-183.

16. Rayman MP, Bath SC.2015. The new emergence of iodine deficiency in the UK. Consequences for child neurodevelopment. Ann Clin Biochem; 52: 705-8.

17. Baye K, Faber M. Windows of opportunity for setting the critical path for healthy growth. Public Health Nutr; 18: 1715-1717. 
18. World Health Organization/ International Council for the Control of the lodine Deficiency Disorders/ United Nations Children's Fund (WHO/ ICCIDD/ UNICEF). 2001. Geneve; World Health Organization.

19. Pretell EA, Delange F, Hostalek U, Corigliano S, Barreda I, Higa AM, et al. 2004. Iodine nutrition improves in Latin America. Thyroid; 14:500-9.

20. Moleti M, Trimarchi F, Vermiglio F. 2014. Thyroid physiology in pregnancy. Endocr Pract; 20: 589-596.

21. Bernal J, Guadaño-Ferraz a, Morte B. 2015.Thyroid hormone transports-functions and clinical implications. Nat Ver Endocrinol; 11: 406-17.

22. Rovet JF. 2014. The role of thyroid hormones for brain development and cognitive function. Endocr Dev; 26:26-43.

23. Obregon MJ, Calvo RM, Del Rey FB, de Escobar GM. 2007. Ontogenegis of thyroid function and interactions with maternal function.Endocr; 10:86-98.

24. Ting E, Syed AA, Kyriacou A. 2016.Bening thyroid disease in pregnancy: A state of the art review. J Clin Transl Endocrinol; 6:37-49.

25. Oguz Kutlu A, Kara C. 2012.lodine deficiency in pregnant women in apparently iodinesufficient capital city of Turkey. Clin Endocrinol; 77: 615-20.

26. Bath SC, Pop VJ, Furmidge-Owen VL, Broeren MA, Rayman MP.2016.Thyroglobulin as a functional biomarker of iodine status in a cohort study of pregnant women in United Kingdon. Thyroid; 27: 426-33.

27. Ribeiro RCJ, Apriletti JW, West BL, Wagner RL, Fletterck RJ, Schaufele, et al.1995. The molecular biology of thyroid hormone action. Ann NY Acad Sci; 758:366-89.

28. Dunn JT, Dunn AD. 2001. Update on intrathyroidal iodine metabolism. Thyroid; 11(5):40714.

29. Laurberger P. 1993. lodine deficiency disorders and endemic goiter.Europ Clin Nutri 47:1-8.

30. Andersen S, Karmisholt J, Pedersen KM, Laurberg P. 2008. Reliability of studies of iodine intake and recommendations for number of samples in groups and individuals $\mathrm{Br} J \mathrm{Nutr}$; 99:813-

31. Knobel M, Medeiros-Neto G. 2004. Moléstias Associadas à Carência Crônica de lodo. Arq Bras Endocrinol Metab; 48 (1): 53-61.

32. Zimmermann MB, Jooste PL, Pandav ChS. 2008. lodine-deficiency disorders .Lancet; 372:1251-62.

33. Zimmermann MB. 2009. Iodine deficiency.Endocr Ver 30: 376-408.

34. Navarro AM, Oliveira LA, Meirelles JCS, Costa TMB. 2010. lodação do sal e ingestão excessiva em crianças. Arch Latinam Nutr; 60 (4): 355-9.

35. Camargo RY, Tomimori EK, Neves SC, Rubio GS, Gairão AL, Knobel M, Medeiros-Neto G. 2008. Thyroid and environment exposure to excessive nutrition iodine increases: the prevalence of thyroid disorders in São Paulo, Brazil. Eur J Endocrinol; 159 (3): 293-9. 
36. Alves MLD. 2016. Inquérito nutricional para avaliação indireta da ingesta de iodo por transeuntes voluntários de uma praça central de Ribeirão Preto, São Paulo.Ver Bras Nutr Clin; 31 (2): 97-100.

37. Chao H, Zhang YE, Liu P, Han YE, Liu SJ. 2016. Relationship between iodized content in household salt and thyroid volume distribution in children. Biomed Environ Sci; 29 (6): 391-7.

38. Greenspan FS. A glândula tireoide. In: Greenspan FS, Gardner DG, eds. Endocrinologia clínica e básica.7ed Porto Alegre: AMGH; 2006. P181-202.

39. Oetting A, Yen PM. 2007.New insights into thyroid hormone action. Best Pract Res Endocrinol Metab; 21 (2):193-208.

40. Krause K, Karger S, Gimm O, Sheu SY, Dralle H, Tannapfel A, et al. 2007.Characterization of DEHAL 1 expression in thyroid pathologies. Eur J Endocrinol; 156 (3): 295-301.

41. Masini-Repiso AM, Coleoni AH, Pelizas CG.Biossíntese, transporte e mecanismo de ação dos hormônios tireoidianos. In: Carvalho MB editor. Tratado de tireoide e paratireoide. Rio de Janeiro: Rubio; 2007. P39-59.

42. Brix K, Führer D, Liebermann H. 2011. Molecules important for thyroid hormone synthesis and action: known facts and future perspectives. Thyroid Res; 4 Suppl 1:59.

43. Larsen PR, Davies TF, Schlumberger MJ, Hay ID.Thyroid physiology and diagnostic evaluation of patients with thyroid disorders. In: Kronenberg HM, Melmed S, Polonsky KS, Larsen R editors. Williams textbook of endocrinology. 11 $1^{\text {th }}$ ed. Philadelphia: WB Saunders; 2007. P 299-315.

44. Alves MLD, Duarte GC, Navarro AM, Tomimori EK. 2010. Avaliação ultrassonográfica da tireoide, determinação da iodúria e concentração de iodo em sal de cozinha utilizado por escolares de Ribeirão Preto, São Paulo, Brasil. Arq Bras Endocrinol Metab; 54 (9) 813-8.

45. Moog NK, Estringer S, Heim C, Wadhwa PD, Kathmann N, Buss C.2017.Influence of maternal thyroid hormones during gestation on fetal brain development. Neuroscience; 342: 68-100.

46. Mohan V, Sinha RA, Pathak A, Rastogi L, Kumar P, Pal A, Godbole MM. 2012.Maternal thyroid hormone deficiency affects the fetal neocortcogenesis by reducing the proliferating pool, rate of neurogenesis and indirect neurogenegis. Exp Neurol; 1237:477-88.

47. Kohwi M, Doe CQ. 2013.Temporal fate specification and neural progenitor competence during development. Nat Rev Neurosci; 14:823-38.

48. Lavado-Autric R, Ausó E, Garcia-Velasco JV, Arufe Mdel C, Escobar del Rey F, Berbel P et al. 2003.Early maternal hypothyroxinemia alters histogenesis and cerebral cortex cytoarchiteture of the progeny. J Clin Investigation;111:1073-82.

49. De Escobar GM, Obregón MJ, del Rey FE. 2007. lodine deficiency and brain development in the first half of pregnancy.Public Health Nutr;10: 1554-70.

50. Min H, Dong J, Wang Y, Teng W, Xi Q, Chen J. 2016. Maternal hypothyroxinemia-induced neurodevelopmental Impairments in the progeny. Mol Neurobiol 2;16, (53): 1613-24.

51. Furnica RM, Lazarus JH, Gruson D, Daumerie C. 2015. Update on a new controversy in endocrinology: Isolated maternal hypothyroxinemia. J Endocrinol Invest; 38: 117-23. 
52. Akturk M, Oruc AS, Danisman N, Erkek S, Buyukkagnici U, Unlu E, et al.2013. Na+/Isymporter a type 3 iodothyronine desiodase gene expression in amniotic membrane and placenta and its relationship to maternal thyroid hormones. Biol Trace Elem Res;154:338-44.

53. Calvo RM, Jauniaux E, Gulbis B, Asunción M, Gervy C, Contempré B, et al. 2002.Fetal tissues are exposed to biologically relevant free thyroxine concentrations during early phases of development. J Clin Endocrinol Metab; 87,1768-77.

54. Kester MH, Martinez de Mena R, Obregon MJ, Marinkovic D, Howatson A, Visser TJ, et al.2015. lodothyronine levels in the human developing brain.Major regulatory roles of iodothyronine desiodases in different areas. J Clin Endocrinol Metab; 89: 3117-28.

55. Maia AL, Goemann IM, Meyer EL, Wajner SM. 2011.Desiodases: The balance of thyroid hormone: Type 1 iodothyronine desiodase in human physiology and disease. J Endocrinol; 209, 283-97.

56. Henrichs J, Ghassabian A, Peeters RP, Tiemeir H. 2013.Maternal hypothyroxinemia and effects on cognitive functioning in childhood: How and why? Clin Endocrinol;79:152 -162.

57. Hynes KL, Otahal P, Hay I, Burgess JR.2013.Mild iodine deficiency during pregnancy is associated with reduced educational outcomes in the offspring: 9-year follow-up of the gestational iodine cohort. J Clin Endocrinol Metab; 98: 1954-62.

58. Strich D, Karavani G, Edri S, Gillis D. 2016.TSH enhancement of FT4 to FT3 conversion is age dependent. Eur J endocrinol; 175: 49-54.

59. Dosiou C, Medici M.2017. Management of endocrine disease: isolated maternal hypothyroxinemia during pregnancy: knowns and unknowns. Eur J Endocrinol;176, R21-R38.

60. Abel MH, Caspersen LH, Meltzer HM, Haugen M, Brandlistuen RE, Aase H, Alexander J, Torheim LE, Brantsaert AL.2017. Suboptimal maternal iodine intake is associated with impaired child neurodevelopment at 3 years of age in the Norwegian mother and child cohort study. J Nutr;147:1314-24.

61. Stenzel D, Huttner WB.2013. Role of maternal thyroid hormones in the developing neocortex and during human evolution. Front.Neuroanat;7:1-9.

62. Li M, Eastman CJ.2012. The changing epidemiology of iodine deficiency. Nat Rev Endocrinol; 8:434-40.

63. Fetene DM, Betts KS, Alati R. 2017.Mechanisms in Endocrinology:Maternal thyroid dysfunction during pregnancy and behavioral and psychiatric disorders of children: $A$ systematic review. Eur j Endocrinol;177,R261-R273.

64. Andersen SL, Lauberger P, Wu CS, Olsen J. 2014. Attention deficit hyperactivity disorder and autism spectrum disorder in children born to mothers with thyroid dysfunction. A Danish nationwide cohort study. BJOG;121:1365-74.

65. Vermiglio F, Lo Presti VP, Moleti M, Sidoti M, Tortorella G, Castagna MG, et al. 2004. Attention deficit and hyperactivity disorders in offspring of mothers exposed to mild-moderate iodine deficiency: A possible novel iodine deficiency disorder in developed countries. J Clin Endocrinol Metab; 89: 6054-60. 
66. Oostenbroek MHW, Kersten RHJ, Tros B, Kunst AE, Vrijkotte TGM, Finken MJJ,et al 2017.Maternal hypothyroxinemia in early pregnancy and problem behavior in 5-year-old offspring. Psychoneuroendocrinology;81;29-35.

67. Modesto T, Tiemieir H, Peeters RP, Jaddoe VW, Hofman A, Verhulst FC, et al. 2015.A maternal mild thyroid hormone insufficiency in early pregnancy and attention-deficit/ hyperactivity disorder symptoms in children. JAMA Pediatr; 169:838-45.

68. Britto PR, Lye SJ, Proulx K, Yousafzai AK, Matthews SG, Vaivada T, et al. 2017.Nurturing care: Promoting early-childhood development. Lancet ;389: 91-102.

69. Velasco I, Bath SC, Rayman MP.2018. lodine as essential nutrient during the first 1000 days of life. Nutrients; 10, 290; doi:10.3390/nu1003029.

70. Daelmans B, Darmstad GL, Lombardi J, Black MM, Britto PR, Lye S, et al. 2017. Early Childhood Development Series Steering Committee. Early childhood development: The foundation of sustainable development.Lancet; 389: 9-11.

71. Agrett P, Niccolai F, Rago T, De Marco G, Molinaro A, Scutari M, et al. 2014.BRAF mutation analysis in thyroid nodules with indeterminate cytology: our experience on surgical management of patients with thyroid nodules from an area of borderline iodine deficiency. J Endocrinol Invest; 37(10): 1009-14.

72. Wang F, Wang Y, Wang L, Wang X, Sun C, Xing M, et al. 2014.Strong association of high urinary iodine with thyroid nodule and papillary thyroid cancer.Tumour Biol ; 35 (11):11375-9.

73. Zimmermann MB. 2014.Thyroid gland: iodine deficiency and thyroid nodules. Nat Rev Endocrinol; 10(12): 707-8.

74. Zhao H, Li H, Huang T.2018. High urinary iodine, thyroid autoantibodies, and thyroidstimulating hormone for papillary thyroid cancer risk. Biol Trace Elem Res; 184(2):317-24. 


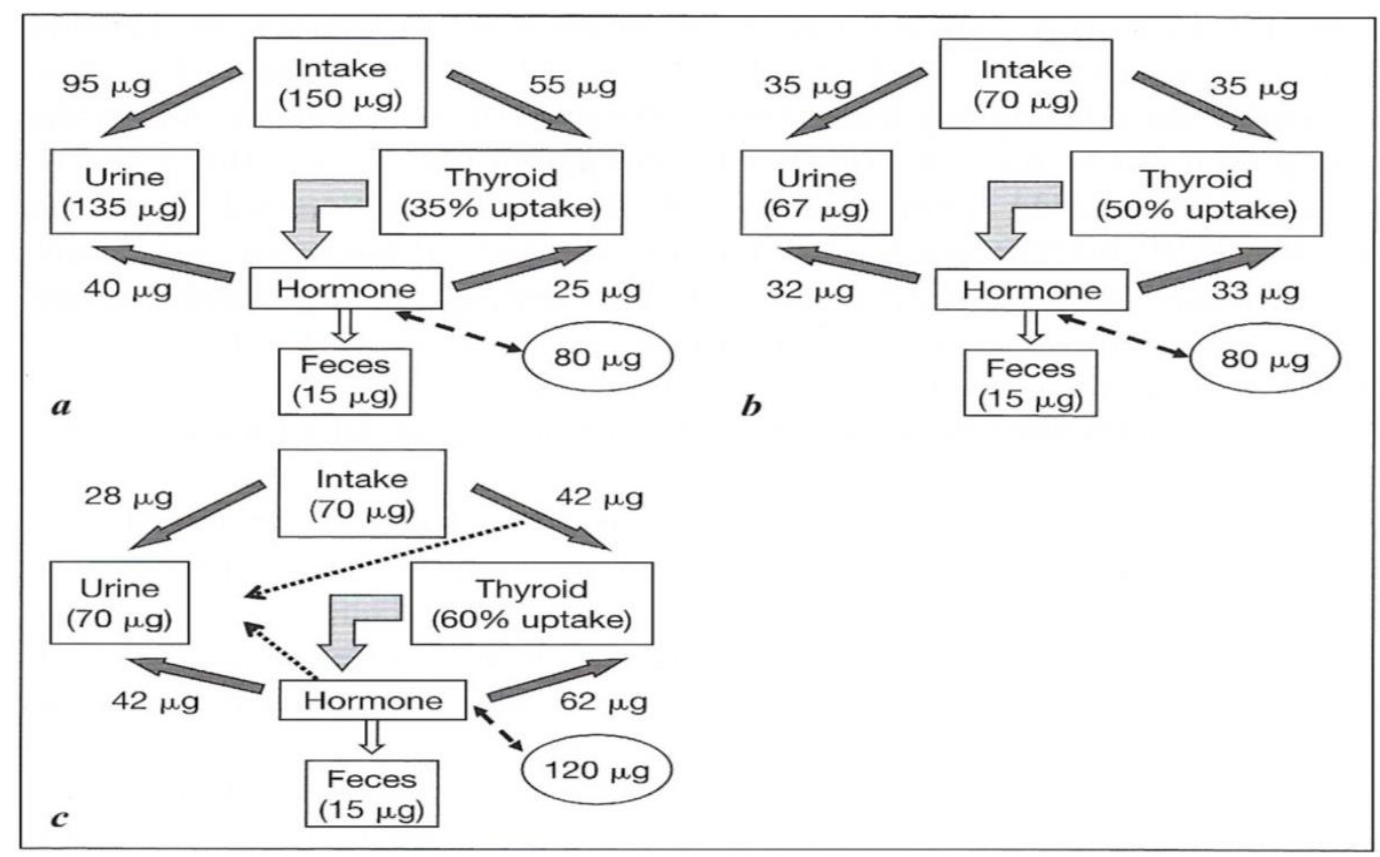

Schematic representation of iodide in human:

a) Human healthy non pregnant adult

b) Human healthy pregnant adult

c) Human pregnant adult under restricted level of iodine intake

( from Glinoer: " Disorders of Thyroid Gland- Thyroid Gland - Development and Function- eds Vliet G Van, Polak M) ( Endocrine development vol 10 pg 65); Karger. 